\title{
Komplex iskolai egészségnevelő program a COM-B modell tükrében
}

\author{
Introduction to a complex school-based health education program \\ from the COM-B model's perspective
}

Szerzők: $\quad$ Eörsi Dániel ${ }^{a} \bowtie$, Herczeg Vivien ${ }^{b}$, Árva Dorottyac ${ }^{c}$, Terebessy András ${ }^{c}$ a: Semmelweis Egyetem ÁOK, Balassagyarmati Egészségnevelő Program, b: Semmelweis Egyetem, I. számú Gyermekgyógyászati Klinika, Balassagyarmati Egészségnevelő Program, c: Semmelweis Egyetem ÁOK, Népegészségtani Intézet, Balassagyarmati Egészségnevelö Program

Beküldve: 2019. 11. 25.

doi: $\quad$ 10.24365/ef.v60i2.540

Összefoglaló: A biztonságos egészségmagatartásra való nevelés szempontjából a serdülőkor kiemelten fontos időszak. Jelen tanulmányban egy komplex, pedagógiai, ifjúságpszichológiai és orvos-szakmai szempontok mentén fejlesztett, kortársoktatáson alapuló iskolai egészségnevelő-programot mutatunk be a COM-B modell tükrében. A COM-B modell szerint a viselkedést (behaviour - B) befolyásoló tényezőket alapvetően három csoportba lehet rendezni, ezek a képesség (capability - C), a lehetőség (opportunity - O) és a motiváció (motivation - M). Programunk, a Balassagyarmati Egészségnevelő Program kiemelt hangsúlyt fektet a célcsoport tagjainak tudásbővítésére (C), a pozitív egészségmagatartást előmozdító környezet megteremtésére $(\mathrm{O})$ és jutalmazáson, valamint személyes interakciókon keresztül a motiváció mélyítésére (M).

Kulcsszavak: iskolai egészségnevelés; kortársoktatás; COM-B modell; gamifikáció; serdülőkor

Summary: Adolescence is a very important period in terms of education for safe health behaviour. The present study introduces a complex school-based health education program developed along pedagogical, youth-psychological and medical aspects, based on peer education, presented from the COM-B model's perspective. According to the COM-B model, the factors influencing behaviour (B) can be grouped into three categories basically: capacity (C), opportunity (O) and motivation (M). Our program, the Balassagyarmat Health Education Program puts a special emphasis on expanding the knowledge of the target-group members (C), developing an environment that promotes positive health behaviour $(\mathrm{O})$ and deepening motivation (M) through rewarding and personal interactions.

Keywords: school-based health education; peer education; COM-B model; gamification; adolescence 


\section{BEVEZETÉS}

Az egészség megőrzésének és a betegségek megelőzésének szempontjából a környezeti, genetikaibiológiai és társadalmi tényezők, valamint az elérhető egészségügyi ellátás minősége mellett kiemelkedő jelentősége van az emberek életmódjának. Az egészséget alakító hatások közül az életmód a klasszikus Lalonde-jelentés ${ }^{1}$ és a legtöbb, azóta keletkezett elemzés szerint is $43 \%$-os súllyal szerepel (miközben a teljes egészségügyi ellátó rendszer súlya $11 \%$ csupán). ${ }^{2,3}$ Örvendetes módon szerte a világon és Magyarországon is egyre nagyobb figyelmet kap az egészségnevelés, azaz az egyén és a közösség tudásának, egészségmagatartásának oktatási módszerekkel való fejlesztése. ${ }^{4}$

\section{$A z$ iskolai egészségnevelés jelentősége}

Minden cselekedetünknek hatása van az egészségünkre. Egészségmagatartás alatt az egészségünk megőrzésére, helyreállítására irányuló tevékenységeink összességét értjük. Szokásaink egész életünkben alakulnak, ezért bármely életkorban van létjogosultsága az egészségnevelésnek - ám a legtöbb program a gyermek és serdülő korosztályt célozza. Óvodáskorban a kockázati tényezők közül a kiegyensúlyozatlan táplálkozás és a passzív dohányzás van a figyelem középpontjában, ezért ebben az időszakban elsősorban játékos, interaktív formában megkezdhetjük a higiéniai és kiegyensúlyozott táplálkozásfókuszú, valamint a dohányzásellenes egészségnevelést. Az általános iskolások körében lehetőség nyílik az elméleti központú oktatásra, például az egészségkockázati magatartásformák káros hatásainak ismertetésére. A serdülő korosztály életében már szinte valamennyi, hosszú távon releváns egészségmagatartási tényező jelen van, ezért a 7.-12. osztályos célcsoport körében mindenképp komplex, több témát felölelő egészségnevelési programok elindítására kell törekedni. Magyarországon jogszabály határozza meg az iskolai egészségfejlesztés keretrendszerét. A teljeskörű iskolai egészségfejlesztésről (TIE) szóló rendelet szerint a megfelelő iskolai egészségnevelés - a kampányszerű programokkal ellentétben - folyamatosságra törekszik, és széles körben igyekszik bevonni a köznevelés résztvevőit, így az adott iskola minden tanulója, a teljes tantestület, a szülők és az iskolafenntartó bevonását is célozza. ${ }^{5}$

\section{Serdülőfókuszú egészségnevelő programok jellemzői}

Az iskolai egészségnevelő programok tematikája, módszertana igen szerteágazó, és - amennyiben volt hatékonyságvizsgálat - hatékonyságukkal kapcsolatban is jelentősen eltérő adatokat közölnek a tanulmányok.

\section{Témák}

A nemzetközi irodalomban számos egészségnevelő programmal találkozunk, melyek fókuszában többnyire a szexuális egészség, a HIV-megelőzés, illetve a dohányzás és a káros szerhasználat megelőzése áll. 2,6,7,8,9,10 Egyéb elterjedt témák az asztma, az egészséges étrend, fertőzések és antibiotikumhasználat, illetve a kézmosás jelentősége. ${ }^{2}$ előbb Az itthon megvalósult programok közül is a legtöbb a szexuális egészségnevelést a dohányzás, az alkoholés drogfogyasztás megelőzését, valamint az egészséges táplálkozás és a fizikai aktivitás fontosságát hangsúlyozza. Akadnak olyanok, amelyek egy-egy konkrét témát állítanak középpontba (pl.: HAPPY vízprogram a vízfogyasztás ${ }^{11}$, a T.E.S.I. a fizikai aktivitás jelentőségét emeli ki $^{12}$ ), a legtöbb program azonban az elóbb említett témák közül többet is $f$ elölel (a teljesség igénye nélkül: Shapiro ${ }^{13}$, D.A.D.A. ${ }^{14}$, ELLEN-SZER ${ }^{14}$, Egészséges testben, lélekben program ${ }^{15}$, TanTudsz ${ }^{16}$, a Debreceni Egyetem egészségnevelő programja ${ }^{17}$ ). A köznevelésben zajló egészségnevelést szabályozó rendelet is teljes körű, valamennyi fő egészségkockázati tényező befolyásolására irányuló iskolai egészségfejlesztést (TIE) ír elő. ${ }^{5,18}$

\section{Módszertan}

Általában az egészségfejlesztés és ezen belül az egészségnevelés alapvetően nem kívülről beavatkozást jelent, hanem az adott közösségben már fellelhető saját erőforrások (tudás, változási motiváció, már meglévő egészségvédő magatartásmintázatok) mobilizálása, valamint az egészségmagatartásra vonatkozó közösségi normák pozitív irányú befolyásolása is rendkívül fontos. 
Oktatásmódszertan alatt valamennyi oktatási célú, az oktatók és a diákok között létrejövő interakció összességét értjük. Az oktatás történhet személyesen, valamint online felületen. Előbbi során személyes kapcsolat jön létre az oktató és a hallgató között. Az online tér fontossága egyrészt abban rejlik, hogy az információk jelentős részét az inter- neten szerezzük, másrészt technikailag is könnyebben, gyakrabban lehet ezen a csatornán kommunikálni. Mindkét formában lehet az oktatás frontális (egyirányú), ahol a hallgató passzív szereplő, vagy lehet interaktív, ahol a befogadó aktív szerepbe kerül. Az ebből adódó oktatási helyzet-típusokra az 1. táblázatban adunk meg példákat.

1. táblázat: Oktatási helyzetek típusai

\begin{tabular}{|l|l|l|}
\hline \multicolumn{2}{|c|}{ Személyes } & \multicolumn{1}{c|}{ Online } \\
\hline Frontális & Egészségnevelő előadás & E-learning tananyagok \\
\hline Interaktív & Csoportmunka & Online kvíz \\
\hline
\end{tabular}

Forrás: saját szerkesztés

Az iskolai egészségnevelő programokat bemutató irodalomban a konkrét oktatásmódszertan kis mértékben, illetve egyáltalán nem tisztázódik. Vannak olyan közlemények, ahol táblázatban gyűjtötték össze a tantervet és az órákkal elérni kívánt hatást, de a konkrét órai feladatokról nem esik szó (pl.: Listen Up! projekt, Dél-Afrika ${ }^{19}$ ). Máshol külső hivatkozással érhető el a tanrend (pl.: Teen Prevention Education Program, USA ${ }^{9}$ ), a beavatkozás konkrét módjának megjelölése nélkül. Ritka az olyan tanulmány, ahol részletesen leírják, hogy pontosan milyen aktivitásokban vehettek részt a diákok (pl.: e-Bug interaktív tudományos show, Egyesült Királyság²).

Az oktatásmódszertannal kapcsolatos részleges információhiánynak az lehet a magyarázata, hogy a terjedelmi korlátok következtében a módszertant nehéz igazán részletesen megfogalmazni, miközben a tudományos irodalom sajátosságai miatt a kutatási adatokat jobban értékelik az olvasók a módszertani ismertetőknél. Azonban mindez odavezet, hogy egy új egészségnevelő program fejlesztése során nehéz összegyújteni a célcsoport egészségmagatartását hatékonyan befolyásolni képes intervenciókat.

\section{Kortársoktatás}

A kortársoktatás elvét gyakran alkalmazzák egészségnevelési programokban. 2,6,8,9,10,20 Ennek lényege, hogy az egyének a hozzájuk hasonló életkorú, de magasabb képzettségú oktatók segítségével tesznek szert tudásra, sajátítanak el bizonyos készségeket. Ez a pedagógiai módszer tipikusan fiatalok körében ajánlott, de egyéb, sajátos közösségi helyzetekben is indokolt lehet, például emelkedett HIV-rizikóval élő csoportok esetében. ${ }^{21}$ A módszert alátámasztó egyik legfontosabb, legtöbbet idézett elmélet Bandura szociális tanuláselmélete (social learning theory). A kognitív pszichológia fejlődésében is sarokkőnek számító, „modelltanulás-elmélet"-nek is nevezett megközelítés szerint új viselkedésmódokat a kívánatos mintául szolgáló másik személy megfigyelésével, utánzásával tudunk elsajátítani akkor, ha hozzá hasonlónak éljük meg magunkat, azonosulni tudunk vele. Az elmélet a felnőttkori tanulásra is érvényes, azonban a gyermekek, fiatalok tanulási folyamatainak megértését hangsúlyozottan szolgálja. 22,23

A kortársoktatásnak számos előnye van a hagyományos pedagógiai módszerekhez képest, ugyanakkor kritikát is megfogalmaztak vele kapcsolatban. ${ }^{2,6,8,9,10,20}$ Ezeket a 2. táblázatban foglaljuk össze.

\section{Hatékonyság}

Mind a nemzetközi, mind a hazai iskolai egészségfejlesztési programok vonatkozásában jellemző, hogy a hatékonyságuk vizsgálatára ritkán kerül sor, miközben tudható, hogy mindenfajta intervenció szerves részét kell, hogy képezze a visszacsatolás, a beavatkozás eredményességének ellenőrzése. Ezen adatok fényében nyílik lehetőség ugyanis az intervenció értékelésére, továbbfejlesztésére, a szükséges változtatások megtételére. ${ }^{33} \mathrm{~A}$ kisszámú, hatékonyságot vizsgáló tanulmányok eredményeit összesítő tanulmányok pozitív vagy vegyes eredményekről számolnak be. ${ }^{7,24}$ 


\begin{tabular}{|c|c|c|}
\hline & ELŐNYÖK & HÁTRÁNYOK \\
\hline $\begin{array}{l}\text { A befogadók } \\
\text { szemszögéből: }\end{array}$ & $\begin{array}{l}\text { - a diákok a hasonló életkor miatt jobban } \\
\text { tudnak azonosulni oktatóikkal } \\
\text { - a diákok kortársaikra hitelesebb információ- } \\
\text { forrásként tekintenek, mint az idősebbekre } \\
\text { - a kortársoktatókkal bizalmasabb kapcsolatot } \\
\text { tudnak kialakítani, a tabunak számító téma- } \\
\text { körökről könnyebben tudnak velük beszél- } \\
\text { getni (pl. kábítószer-használat, szexualitás) } \\
\text { - optimális esetben a kortársoktatók pozitív } \\
\text { példaképekké is válnak számukra } \\
\text { - a kortársoktatók egységes felkészítést kap- } \\
\text { nak a program elején, így ugyanazt a szem- } \\
\text { pontrendszert képviselik az oktatás során } \\
\text { - a folyamatos kapcsolattartás gyakori jel- } \\
\text { lemző, ami szintén segíti a bizalom kialakulá- } \\
\text { sát és elmélyítését, ezáltal növeli a program } \\
\text { hatékonyságát }\end{array}$ & $\begin{array}{l}\text { - az oktatók nem rendelkeznek szakké- } \\
\text { pesítéssel, ezért egyes speciális kér- } \\
\text { désekben a diákok nem jutnak } \\
\text { professzionális szakmai segítséghez } \\
\text { - a kortársoktatók nem képzett peda- } \\
\text { gógusok, ezért bizonyos nehéz cso- } \\
\text { porthelyzetek kevésbé oldódnak meg }\end{array}$ \\
\hline $\begin{array}{l}\text { A kortársoktatók } \\
\text { szemszögéből: }\end{array}$ & $\begin{array}{l}\text { - az órákra való felkészülés közben maguk is } \\
\text { új ismeretekre tehetnek szert, mélyíthetik } \\
\text { korábban megszerzett, egészséggel kapcso- } \\
\text { latos tudásukat } \\
\text { - hozzáállásukra, magatartásukra és életmód- } \\
\text { jukra is pozitív hatással lehet } \\
\text { - javíthatja önértékelésüket } \\
\text { - fejleszti kommunikációs és szociális készsé- } \\
\text { geiket } \\
\text { - segítő foglalkozásra irányuló képzésben } \\
\text { részt vevő kortársoktatók számára az } \\
\text { oktatási helyzet modellezheti a segítői } \\
\text { kapcsolatot }\end{array}$ & $\begin{array}{l}\text { - előfordul, hogy nem érzik megfele- } \\
\text { lően felkészültnek magukat } \\
\text { - nem tudnak professzionális szakmai } \\
\text { segítséget nyújtani } \\
\text { - gyakran túl sokat várnak el tőlük } \\
\text { - sokszor nem tisztázott a hatáskörük } \\
\text { - előbbiek miatt megélhetik a „nem va- } \\
\text { gyok elég jó”, „„nem vagyok eléggé } \\
\text { kompetens” érzést }\end{array}$ \\
\hline $\begin{array}{l}\text { Fenntarthatóság } \\
\text { szempontjából: }\end{array}$ & $\begin{array}{l}\text { - költséghatékony módszer } \\
\text { - oktatási környezetben kedvező toborzási, } \\
\text { mozgósíthatósági viszonyok }\end{array}$ & $\begin{array}{l}\text { - a kortársoktatók toborzása nehézsé- } \\
\text { gekbe ütközhet a tanulmányaikból } \\
\text { adódóan }\end{array}$ \\
\hline
\end{tabular}

Forrás: saját szerkesztés

\section{COM-B - modell az iskolai egészségnevelésben}

A COM-B a képesség (capability), lehetőség (opportunity), motiváció (motivation) és viselkedés (behaviour) szavak angol megfelelőiből kialakított akroníma. Az emberek viselkedését magyarázó COM-B modellt Michie és munkatársai dolgozták ki 2011-ben, szintetizálva számos, akkor ismert, viselkedésváltozást leíró elméletet. A modell hivatkozottsága magas, magyar fordítása Vitrai és Kimmel 2015-ös tanulmányában szerepel először. ${ }^{25,26,27} \mathrm{Az}$ elmélet szerint az emberek magatartását, és így egészségmagatartását is számtalan tényező befolyásolja, ezek azonban három csoportba rendezhetők: képesnek kell lennünk a cselekedetre, lehetőségünk kell, hogy legyen rá, és motiváltnak kell lennünk a megtételére. Érdekesség, hogy a modell hátterében álló megfontolások közül az egyik az amerikai büntető jog, melynek értelmében három dolgot kell bizonyítani ahhoz, hogy az egyént búnösnek nyilvánítsák: volt-e eszköze, illetve képessége az elkövetésre, volt-e rá lehetősége, és volt-e indítéka. ${ }^{25}$

A COM-B modellben a képesség, a lehetőség (vagy más fordításban környezet) és a motiváció viszonyát vizsgálva kölcsönös interakciókkal jellemezhető rendszert kapunk: a három tényező és a hozzájuk 
tartozó altényezők kölcsönösen hatnak egymásra, és kialakítják a viselkedést, ami pedig visszahat ezekre az összetevőkre.25'26'27 [1. ábra]

Az iskolai egészségfejlesztés irodalmában számos programot és megvalósithatósági tanulmányt találunk, melyek kialakításánál a COM-B modellt vették alapul. ${ }^{28,29,30,31,32} \mathrm{~A} 3$. táblázatban bemutatjuk a modell által leírt tényezőket, a példákat pedig az iskolai egészségnevelés területéről hozzuk. 25,26,27
Egészségnevelő program tervezésénél célszerú törekedni arra, hogy az intervenció mind a hat tényezőt megcélozza, mert a viselkedésváltozás így segíthető elő a lehető leghatékonyabban. Ezért lehetséges az, hogy a hagyományos, tárgyi tudás-átadáson (tehát elsősorban a szellemi képesség fejlesztésén) alapuló egészségnevelő programok hatékonysága megkérdőjelezhető.

1. ábra: A COM-B modell: a magatartásváltoztatás rendszere

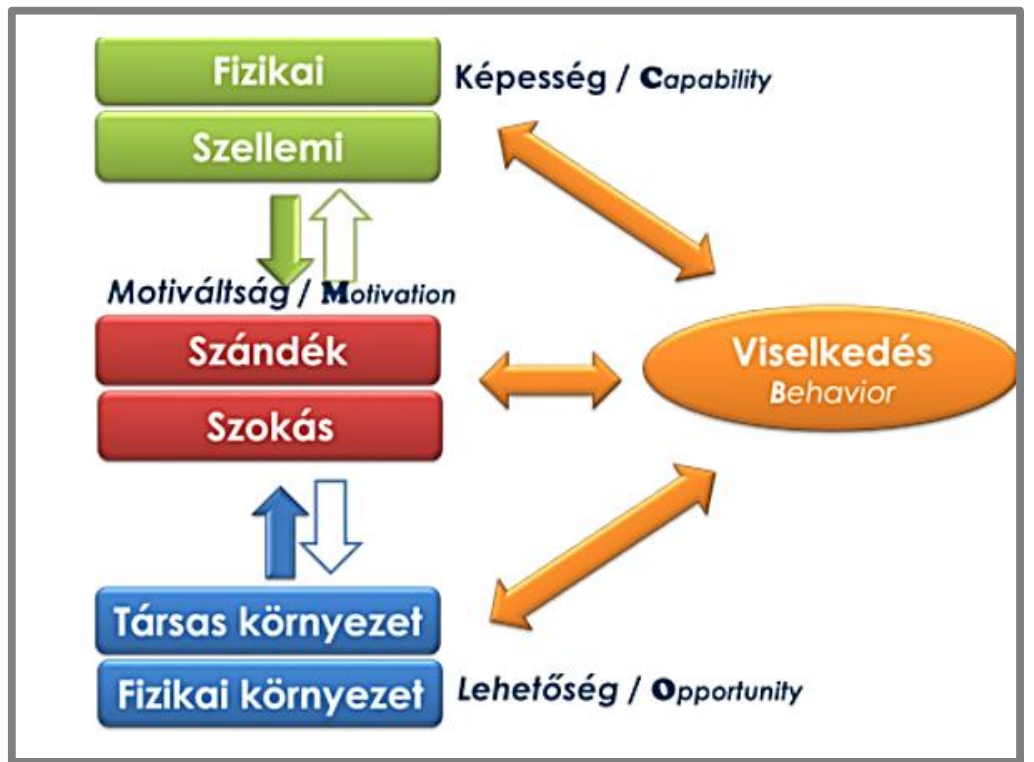

Forrás: Balku, Berki, Csizmadia, et al. (2015) 33

3. táblázat: A viselkedésváltozás tényezőit leiró COM-B modell bemutatása

\begin{tabular}{|c|c|c|c|}
\hline Főtényezők & A főtényezők meghatározása & Altényezők & Példák az egyes altényezőkre \\
\hline \multirow{2}{*}{ Képesség } & \multirow{2}{*}{$\begin{array}{l}\text { Az egyén vagy a közösség ismeretei- } \\
\text { nek és a viselkedés megvalósításá- } \\
\text { hoz szükséges testi és lelki készsé- } \\
\text { geknek összessége. }\end{array}$} & Fizikai & $\begin{array}{l}\text { Megfelelő egészségi állapot (pl. érzék- } \\
\text { szervek, mozgásszervek, kondíció) }\end{array}$ \\
\hline & & Pszichológiai & Tárgyi tudás, problémabelátás \\
\hline \multirow[b]{2}{*}{ Motiváció } & \multirow{2}{*}{$\begin{array}{l}\text { A cselekvést aktiváló tudatos dönté- } \\
\text { sek és szándékok, valamint az auto- } \\
\text { matikusan adott válaszok, szokások } \\
\text { együttese. }\end{array}$} & $\begin{array}{l}\text { Reflektív motivá- } \\
\text { ció (=szándék) }\end{array}$ & Döntések, minősítések, tervek és célok. \\
\hline & & $\begin{array}{l}\text { Automatikus mo- } \\
\text { tiváció (=szokás) }\end{array}$ & $\begin{array}{l}\text { Érzelmek, impulzusok, amelyek asszociá- } \\
\text { ciós tanulásból származnak vagy velünk } \\
\text { születettek }\end{array}$ \\
\hline \multirow{2}{*}{$\begin{array}{l}\text { Lehetőség = } \\
\text { környezet }\end{array}$} & \multirow{2}{*}{$\begin{array}{l}\text { Az összes olyan tényező, amelyek az } \\
\text { egyénen kívül állnak, és a viselke- } \\
\text { dést lehetségessé teszik vagy ösz- } \\
\text { tönzik. }\end{array}$} & Fizikai & $\begin{array}{l}\text { Fizikai környezet által biztosított ténye- } \\
\text { zők (levegő és víz minősége, infrastruk- } \\
\text { túra stb.) }\end{array}$ \\
\hline & & Társadalmi & $\begin{array}{l}\text { Kulturális miliő, társadalmi normák, } \\
\text { anyagi lehetőségek }\end{array}$ \\
\hline
\end{tabular}

Forrás: saját szerkesztés 


\section{A BALASSAGYARMATI EGÉSZSÉGNEVELŐ PROGRAM (BEP) BEMUTATÁSA}

A Semmelweis Egyetem balassagyarmati telephelyén 2017-ben indult el a komplex iskolai egészségnevelést irányzó Balassagyarmati Egészségnevelő Program (BEP). A részt vevő diákok körét a település mind az öt középiskolájának kilencedik és tizedik osztályos tanulói alkotják, az oktatók pedig a Semmelweis Egyetem hallgatói közül kerülnek ki. A program központi gondolata az, hogy már a serdülók is rendelkeznek mindazokkal a fizikai képességekkel, amelyek lehetővé teszik az egészséges, hosszú távú kockázatcsökkentést jelentő életmód kialakítását, azonban sokszor hiányzik az ehhez szükséges támogató környezet, tudás és motiváció. Célunk tehát ezen hiányzó tényezők pótlása; az egészségesség mint közösségi norma kialakítása, a legfontosabb egészségkockázati tényezők tisztázása, és a kiküszöbölésükhöz szükséges magatartásmintázatok közös felfedezése, valamint az elsajátításukhoz szükséges motiváció erősítése. Mindezeken felül az egészségtudatos döntések meghozatalát a diákok meglévő személyes erőforrásainak mobilizálásán keresztül is igyekszünk támogatni.

\section{Regionális jellegzetességek}

Magyarország különösen terhelt a lakosság egészségkárosító magatartása szempontjából. Az OECDországok közül Magyarországon a harmadik legmagasabb a dohányzási arány, és a negyedik legnagyobb az elhízottak aránya. ${ }^{34} \mathrm{Az}$ északmagyarországi régió egész Európa egyik legkedvezőtlenebb szocioökönómiai státusszal jellemezhető területe, például az összesen 272 európai uniós régió közül itt a legmagasabb a korai, azaz 65 éves kor előtti halálozás aránya. ${ }^{10}$ Balassagyarmat a régió egyik legnyugatibb járásának központja, lakosságszáma közel 20 000, vonzáskörnyezetében további 30000 ember él.

\section{Tematika és módszertan a BEP-ben}

A BEP fókuszában nem önmagában valamelyik egészségrizikó csökkentése, hanem általában az egészség fejlesztése áll. Ebből következően a program során széles spektrumban érintjük az egészséges életmód különböző területeit (a konkrét témákról bővebben a pszichológiai képesség alfejezetben írunk).

A BEP segítségével az egészségnevelés gimnáziumi, szakgimnáziumi és szakközépiskolai osztályokban képzéstípustól függetlenül azonos formában zajlik. Az oktatás során az egészségfejlesztő előadáson kívül minden további, az 1. táblázatban szereplő módszertant alkalmazunk.

A személyes, offline egészségnevelés interaktív, kiscsoportos formában folyik a kortársoktatás keretei között. Célunk az adott csoportban fellelhető személyes egészségfenntartó erőforrások (tudás, változási motiváció, már meglévő egészségvédő magatartásmintázatok) azonosítása, mobilizálása, megerősítése és a felmerülő kérdések tisztázása. Ezért a frontális oktatásformákat tudatosan kerüljük, az új ismeretek átadása is a csoporttagok aktív részvételére épülő aktivitások során zajlik. Szintén kerüljük az elrettentésen alapuló egészségnevelést, mert a félelmet nem tekintjük a tartós viselkedésváltozás lehetséges alapjának. Kortársoktatóink a csoportokban törekszenek a biztonságos, konstruktív légkör kialakítására, amely szükséges az egyéni szempontok és meglátások kibontakoztatásához, a kérdések felvetéséhez. A hatékony és reflektív csoportfolyamatok elősegítése végett kiscsoportos oktatást végzünk maximum 15 résztvevővel, két oktatóval. Így évfolyamonként az öt középiskolában összesen 27-30 oktatási csoport jön létre. ${ }^{35}$

Ezeken felül kiemelt figyelmet fordítunk az oktatás gamifikálására, játékos alapra helyezésére is, ami egyfelől segít fenntartani a diákok motivációját az új ismeretek elsajátítása során, másfelől ilyen módon élményhez kapcsoltan és így tartósabban, hatékonyabban rögzülhetnek az információk. ${ }^{36}$ Valamenynyi aktivitás során egyéni és csoportos jutalompont szerezhető, melyek tárgyi nyereményekre vagy speciális programokon részvételre válthatók át.

Kortársoktatóink félévente mintegy 18 órás képzésben részesülnek, mely során egyrészt tartalmi, másrészt módszertani ismeretekkel gazdagodnak. Ezen alkalmak biztosítják, hogy minden oktató megfelelő tudással rendelkezzen a program által érintett témakörök területén, valamint felkészítik őket a kiscsoportos, interaktív oktatási helyzet, illetve a gamifikáció sajátosságaira is. Célunk, hogy oktatóink megszerezzék a számukra is újszerű szemléletű, struktúrájú órák moderálásához szükséges kompetenciákat. 
Az online tananyagok egy közös, minden diák számára hozzáférhető, de kifelé zárt online térben érhetők el. A személyes oktatáshoz hasonlóan valamennyi tananyagunk interaktív, a rövid, ismeretátadásra szolgáló tartalmakhoz számos feladat kapcsolódik. Az online tananyagok böngészése során is építünk a játékos tanulás előnyeire. Az online jutalmazási pontrendszerben szerezhető pontok hozzáadódnak a személyesen megtartott órák aktivitásai alapján szerzett pontokhoz. Minden oktatott témában négy, egyenként mintegy 15 perc alatt kitölthető tananyag készült. Megjegyzendő, hogy saját felmérésünk szerint a diákok internetes hozzáférése 100\%-osnak mondható.

A program során az egészségnevelés folyamatosságának fenntartására különféle módokon törekszünk. Egyrészt az oktatási alkalmak időbeli elosztásával biztosítunk rendszeres jelenlétet, mivel egy éven keresztül, a nyári szünetek kivételével nagyjából havi rendszerességgel, összesen tíz alkalommal találkozunk személyesen célcsoportunk tagjaival. Másrészt egy csoport számára a két kortársoktató személye állandó, az oktató párok végig kísérik csoportjaikat a program egy éve során, és az oktatási alkalmak között a közösen használt online térben is jelen vannak. Az online tananyagok pedig a személyes találkozások közötti időben folyamatosan elérhetők a diákok számára, az itt található feladatok bármikor kitölthetők, a pontok gyújtése a program lezárásáig lehetséges.

Programunk hatékonyságát kvalitatív és kvantitatív elemeket is tartalmazó, többszöri adatfelvételekből álló kutatási programmal igyekszünk megítélni. Az erről szóló eredményeink ismertetése meghaladná jelen tanulmányunk kereteit, ezek közlését a későbbiekben tervezzük.

\section{A BALASSAGYARMATI EGÉSZSÉGNEVELŐ PROGRAM A COM-B MODELL TÜKRÉBEN}

A következőkben bemutatjuk a Balassagyarmati Egészségnevelő Program struktúráját a COM-B modell tükrében.

C- capability (képesség)

\section{Fizikai képesség}

A fizikai képességek fejlesztésével programunk kevéssé foglalkozik. Azt gondoljuk, hogy célcsoportunk tagjainak többnyire megvan a fizikai képessége, hogy egészségesen éljen. A program részeként diákjaink „egészséges vállalás”-okat tesznek, ennek részeként edzésprogramot is végezhetnek, mely felfogható fizikai képesség fejlesztésének. A Balassagyarmati Egészségnevelő Program keretein belül van alapszintű újraélesztés-képzés, melynek középpontjában az Országos Mentőszolgálat laikus BLS-képzéséhez hasonló, gyakorlati, szimulált BLS-tréning áll. ${ }^{37}$

\section{Pszichológiai képesség}

Programunk egyik sarokköve az egészséges életmóddal kapcsolatos alapvető, serdülők számára is hasznosítható tudás átadása, és problémabelátás kialakítása. Mind a személyes találkozások alkalmával, mind az online térben naprakész ismereteket nyújtunk a diákok részére, mely anyagokat folyamatosan fejlesztjük. Ugyanakkor fontosnak tartjuk kiemelni, hogy programunkban a health literacy-t, azaz egészségmúveltség mellett annak gyakorlati felhasználását is fejleszteni szándékozunk.

Szemléltetésül közlünk néhány példát oktatásunk anyagából. A dohányzásprevenció során interaktív munkában tisztázzuk a dohányzás legfontosabb hátrányait és veszélyeit, különös tekintettel a szív- és érrendszeri, valamint a daganatos következményekre. Foglalkozunk a passzív dohányzással, a füstmentes intézményi kultúra terjedéséből származó előnyökkel és a függőség veszélyeivel. A táplálkozás vonatkozásában a legfontosabb üzenetek a megfelelő folyadékbevitel, a természetes alapanyagokból készült ételek szerepének jelentősége, a kalóriaszámlálás alapjai és a szénhidrátok felszívódási sebességével kapcsolatos ismeretek köré csoportosulnak. Kitérünk a mozgás örömére, arra, hogy elvileg nincs preferált mozgásforma, hanem mindenkinek a személyes életéhez, ízléséhez adaptált mozgásmintázat kialakítása a legjobb. A biztonságos szexualitásról szóló órákon törekszünk a nemi müködés anatómiai-élettani hátterének tisztázására, különös tekintettel a serdülőkori változásokra és a fogamzásra. Tisztázzuk a fogamzásgátlás, a nemi 
betegségek megelőzésének szempontjait, különös tekintettel a konzisztens óvszerhasználat jelentőségére, és készségszinten oktatjuk a hatékony fogamzásgátlási módszereket.

Körüljárjuk az esetleges nem kívánt terhesség esetén felmerülő teendőket is. Oktatásunk lényegi része továbbá a nemet mondás gyakorlása az aszszertivitás jegyében. Törekszünk arra is, hogy diákjaink képessé váljanak érdekeik, határaik képviseletére az intim helyzetekben és az online világban is.

\section{O - opportunity (lehetőség, környezet)}

\section{Fizikai környezet}

Egy iskolai egészségnevelő programnak kevés lehetősége van befolyásolni a fizikai környezetet, de kísérletet azért teszünk erre. Például a dohányzásprevenciós órán diákjaink dohányzásellenes plakátokat készítenek, amelyeket az iskolák közös tereiben helyeznek ki.

\section{Társas környezet}

A társadalmi norma alapvetően befolyásolja az egészségmagatartást, ezért programunk nem egyéni szinten, hanem az iskolai osztályok szintjén avatkozik be. A város összes iskolájában jelen vagyunk, egy adott évben valamennyi balassagyarmati 9. és 10. osztályos tanuló részt vesz képzésünkön. Mivel a program négy évet ölel fel, csaknem egész iskolákat vonunk be. A pedagógusokkal intenzív kapcsolatot alakítunk ki, rendszeres tájékoztatást kapnak a program alakulásáról, ezáltal ők is a sajátjuknak érezhetik, képviselni tudják a program szempontrendszerét munkájuk során. Terveink között szerepel, hogy az intervención már átesett, felsőbb osztályos diákok bekapcsolódhatnak a programba kortárs segítőként.

Az egyes témakörökben is kiemelt hangsúlyt helyezünk a társadalmi norma kérdésére. Például a dohányzásprevenciós órán kitérünk a társas nyomás jelentőségére, igyekszünk a közösségi norma szintjén beavatkozni, például „Mi, balassagyarmati diákok nem attól vagyunk menők, hogy dohányzunk, hanem attól, hogy nem dohányzunk.". Az étrenddel és a testképpel foglalkozó oktatás során kiemelt hangsúlyt fektetünk arra is, hogy a média által közvetített ideálkép a testalak és a sportered- mények szempontjából sem követendő, mindenkinek a saját valóságában kell elérnie a saját céljait. A nemi élettel foglalkozó órának célja a szexualitás témájában megjelenő számtalan előítéletre és tévhitre való reflexió is, különös tekintettel a pornográf tartalmak által közvetített sztereotípiákra. Ezért szükséges annak tisztázása is, hogy a szexualitás alapvetően társas, kölcsönös tevékenység, ezért mindenkinek vigyáznia kell saját és partnere érzelmi biztonságára is.

Mentálhigiénés prevenciós programunk célja a nehéz érzelmi állapotok esetén javasolt alapvető támogató attitűd irányába mutató készségfejlesztés, valamint a közösségi és internetes zaklatás és a kiközösítés megelőzése.

M-motivation (motiváció)

Reflektív motiváció (=szándék)

Óráink során arra törekszünk, hogy a konkrét tudás átadásán kívül diákjaink attitúdjére, motivációjára is hatással legyünk. Motivációjuk további felkeltése céljából gamifikált oktatást végzünk: az órák során és az online anyagok kitöltésével versenyben vesznek részt, pontjaikat pedig értékes nyereményekre válthatják be. Az eddigi tapasztalatok alapján sikerült olyan struktúrát kidolgozni, hogy a versenyben való esélyek kevéssé függnek a képzés típusától, a szakközépiskolás diákok ugyanolyan eredményesek lehetnek, mint a gimnazisták.

Például, mint említettük, diákjaink dohányzásellenes plakátokat készítenek, melyeket kreativitás és szakmai tartalom alapján független zsűri pontoz. A legjobb plakátok készítői jutalmat kapnak, tehát a büntetésfókusz (,ha cigizel, beteg leszel és meghalsz”) helyett a jutalmazásfókusz („,ha küzdesz a dohányzás ellen, akkor jót teszel mással és magaddal is") kerül előtérbe.

A képzés során diákjaink és oktatóink is „egészséges vállalásokat" tesznek, azaz néhány reálisan elérhető, pozitív egészségmagatartási mintázat fenntartását tǔzik ki a következő 30 napra. Az eredményekről a közös online térben számolnak be egymásnak. Drogprevenciós tevékenységünk során - mivel a kábítószerek hatásának, veszélyeinek bemutatása paradox módon fokozhatja a kíváncsiságot, növelheti a káros szerhasználatot - az egyes drogok veszélyeinek bemutatása helyett a figyelmet a 
szerhasználathoz vezető állapotok, frusztrációk, vágyak azonosítására, normalizálására, és a szermentes megoldási módok megerősítésére fordítjuk. Célcsoportunk számára a szexuális élet megkezdése aktuális kérdés. Prevenciós tevékenységünk során nem határozunk meg ideális életkort a szexuális élet megkezdése szempontjából. Szemléletünk szerint a belső igényekhez leginkább illeszkedő, biztonságos szexuális élet kialakítása a cél, ezen belül mindenkinek saját döntést kell hoznia a szexuális életének alakulásáról, ebben igyekszünk segíteni a diákokat. Hangsúlyozzuk a tudatos családtervezés sokdimenziós voltát, támogatjuk a személyes ambíciók tisztázását és képviseletét.

\section{Automatikus motiváció (=szokás)}

A személyes találkozások során és az online anyagokban is törekszünk arra, hogy száraz információk közlése és a gondolatindító aktivitások mellett a már meglévő pozitív egészségmagatartásra irányuló szokások is felszínre kerüljenek, megerősödjenek. A diákok pozitív példaképként tekinthetnek kortársoktatóinkra, akik kívánatos mintákat közvetítenek.
A közösségi normák pozitív befolyásolásán, az elérhető egészségvédő magatartásmintázatokhoz társuló nyereségek bemutatásán, az egészségesség hosszú távú kedvező következményeinek prezentálásán és tudatosításán, valamint a már meglévő, jó mintázatokkal kapcsolatos pozitív visszajelzéseken keresztül próbáljuk elősegíteni azt, hogy a pozitív egészségmagatartás kívánatos és követendő cél legyen diákjaink számára.

Például a dohányzásellenes plakátkészítés során a célcsoport tagjai maguk is egészségnevelő szerepkörbe kerülnek, ez pedig fokozza a dohányzásprevenció szempontjaival való azonosulás, még szerencsésebb esetben az internalizáció lehetőségét.

\section{Összefoglaló táblázat}

A Balassagyarmati Egészségnevelő Program a COM-B modell mindhárom determinánsát érinti. A 4. táblázatban összefoglaljuk és a szexuális rizikócsökkentést célzó órák idevágó elemeivel szemléltetjük a program legfontosabb aspektusait.

4. táblázat: A BEP a COM-B modell tükrében - a feltüntetett példák a szexuális rizikócsökkentés témájú órából származnak

\begin{tabular}{|l|l|l|}
\multicolumn{2}{|c}{ Módszertan } & \multicolumn{1}{c|}{ Példák } \\
\hline C & $\begin{array}{l}\text { Szakmailag ellenőrzött, hiteles oktatási ele- } \\
\text { mek. } \\
\text { Az online és személyes térben is a leglényege- } \\
\text { sebb üzenetek ismétlése. }\end{array}$ & $\begin{array}{l}\text { Ismertetjük a nem kívánt terhesség, a nemi úton terjedő, fer- } \\
\text { tőző betegségek és az érzelmileg megterhelő szexuális élmé- } \\
\text { nyek elkerülésének módjait. Asszertivitás, nemet mondás } \\
\text { készségszintű fejlesztése. }\end{array}$ \\
\hline $\mathbf{O}$ & $\begin{array}{l}\text { Beavatkozás a társas környezeti norma szint- } \\
\text { jén. }\end{array}$ & $\begin{array}{l}\text { A csoporton belül lefektetjük annak a normának az alapjait, } \\
\text { hogy az óvszerhasználat minden szexuális együttlét alkalmával } \\
\text { fontos, szükségszerü. }\end{array}$ \\
\hline $\mathbf{M}$ & $\begin{array}{l}\text { Kortársoktatás. } \\
\text { Az óvszerhasználat előnyeinek megvilágítása. } \\
\text { A kortársoktató mint potenciális példakép érvel az óvszerhasz- } \\
\text { nálat mellett. }\end{array}$ \\
\hline
\end{tabular}

Forrás: saját szerkesztés

\section{MEGBESZÉLÉS, AJÁNLÁSOK}

A Balassagyarmati Egészségnevelő Program célja a részt vevő serdülők egészségmagatartási mintázatainak minél hatékonyabb fejlesztése. Komplex, interdiszciplináris program kidolgozása során ötvöződtek az orvosi, ifjúságpszichológiai és pedagógiai szempontok.

A felhasznált irodalom alapján az iskolai egészségnevelés módszertana jelenleg világszerte heterogénnek tekinthető, ami megnehezíti az optimális eszköztár megválasztását, ugyanakkor viszonylagos 
szabadságot is biztosít. A COM-B modell áttekinthető szempontrendszert kínál ilyen programok megtervezéséhez, összeállításához. A modell szerint a viselkedést alapvetően hatféle determináns alakítja; a fizikai és pszichológiai képesség, a fizikai és társas környezet és a reflektív, valamint az automatikus motiváció. Egészségnevelő programok tervezésénél célszerű arra törekedni, hogy a beavatkozás mind a hat determinánst megcélozza, mert a viselkedésváltozás így segíthető elő a lehető leghatékonyabban.

A BEP a fent leírt hat determináns közül hangsúlyozottan irányul a pszichológiai képességre, a társas környezetre, valamint a motiváció mind reflektív, mind automatikus aspektusára. Az egészséges életmódra való fizikai képességet a célcsoport döntó hányadának vonatkozásában adottnak vesszük. A közeljövőben további elemekkel tervezzük bővíteni programunkat, amelyek egy része érintené az így fennmaradó tényezőt, a fizikai környezetet. Az erre irányuló terveink között szerepel elsősorban a balassagyarmati középiskolák környezetében múködő for-profit és non-profit szereplők bevonása (pl.: a büfékben, a környező pékségekben az egészséges alternatívák számának növelése). Mindezeken keresztül reméljük, hogy programunk még hatékonyabb közösségi egészségfejlesztési modellt fog megvalósítani.

Azt gondoljuk, hogy a Balassagyarmati Egészségnevelő Program hatását több lélektani és szociológiai tényezőn át fejti ki, a legfontosabbakat az 5. táblázat foglalja össze.

\section{5. táblázat: A Balassagyarmati Egészségnevelő Program főbb hatótényezői}

Hatótényező

\begin{tabular}{|c|c|}
\hline Tudás & $\begin{array}{l}\text { A program során fejlesztjük a részt vevő diákok elméleti és gyakorlatközpontú } \\
\text { tudását. }\end{array}$ \\
\hline Minta & $\begin{array}{l}\text { A kortársoktatók mint hiteles szereplők személyes mintát közvetítenek, melynek jelentősége a } \\
\text { szociális tanuláselmélet szerint nagy. }\end{array}$ \\
\hline Én-hatékonyság & $\begin{array}{l}\text { Az oktatás során teret biztosítunk annak, hogy a részt vevő diákok saját változási céljaikat } \\
\text { megfogalmazzák, saját erőforrásaikat azonosítsák. Ezen keresztül tisztázódik a célok elérhető- } \\
\text { ségének realitása. }\end{array}$ \\
\hline Attitűd & $\begin{array}{l}\text { A biztonságos testi és érzelmi fejlődés lehetőségét hangsúlyozzuk, ezáltal pozitív irányú atti- } \\
\text { tûdformálást végzünk. }\end{array}$ \\
\hline Norma & $\begin{array}{l}\text { Tekintettel arra, hogy a program a diákok saját szociális környezetében folyik, } \\
\text { lehetőségünk nyílik arra, hogy a közösségi normát alakítsuk a kívánatos egészségmagatartási } \\
\text { mintázatok irányába }\end{array}$ \\
\hline Motiváció & $\begin{array}{l}\text { A gamifikált, jutalmazáson alapuló oktatási struktúra reflektív motivációt biztosít diákjaink szá- } \\
\text { mára. }\end{array}$ \\
\hline
\end{tabular}

\section{Magyarázat}

Forrás: saját szerkesztés

\section{KÖSZÖNETNYILVÁNÍTÁS}

A Balassagyarmati Egészségnevelési Program kidolgozására és megvalósítására a Semmelweis Egyetem balassagyarmati telephelyén bonyolított EFOP-3.4.3-16-2016-00007 pályázat keretén belül kerülhetett sor.

\section{HIVATKOZÁSOK}

Ezúton mondunk köszönetet a programban oktatóként dolgozó önkénteseinknek, a balassagyarmati diákoknak és tanároknak. Ezen felül név szerinti köszönet illeti a szakmai program kidolgozásában közremüködő kollégákat, elsősorban Prievara Tibort, Major Dávidot, Takács Pétert, Kövesdi Andreát, Hajnes Józsefet, Fiam-Szűcs Katalint, Bátri Zsuzsannát és Hegedűs Juditot. 
${ }^{1}$ Glouberman S, Millar J. Evolution of the determinants of health, health policy, and health information systems in Canada. Am J Public Health. 2003;93(3):388-392. DOI:10.2105/ajph.93.3.388

2 Young VL, Cole A, Lecky DM, et al. A mixed-method evaluation of peer-education workshops for school-aged children to teach about antibiotics, microbes and hygiene. J Antimicrob Chemother. 2017;72(7):2119-

2126. DOI: $10.1093 / \mathrm{jac} / \mathrm{dkx083}$

${ }^{3}$ Ádány R. Megelőző orvostan és népegészségtan. http://dtk.tankonyvtar.hu/xmlui/handle/123456789/7389

(Elérve: 2019.11.01.)

${ }^{4}$ https://fogalomtar.aeek.hu/index.php/Eg\%C3\%A9szs\%C3\%A9gnevel\%C3\%A9s (Elérve: 2019.11.25.)

${ }^{5}$ Newby JM, Smith J, Uppal S, et al. Internet-Based Cognitive Behavioral Therapy Versus Psychoeducation Control for Illness Anxiety Disorder and Somatic Symptom Disorder: A Randomized Controlled Trial. J Consult Clin Psychol. 2018;86(1). DOI:10.1037/ccp0000248

${ }^{6}$ Strange V, Forrest S, Oakley A. Peer-led sex education--characteristics of peer educators and their perceptions of the impact on them of participation in a peer education programme. Health Educ Res. 2002;17(3):327-337. DOI:10.1093/her/17.3.327

7 Thomas RE, McLellan J, Perera R. School-based programmes for preventing smoking. Cochrane Database Syst Rev. 2013(4):Cd001293. DOI:10.1002/14651858.CD001293.pub3

${ }^{8}$ Bretelle F, Shojai R, Brunet J, et al. Medical students as sexual health peer educators: who benefits more? BMC Med Educ. 2014;14:162. DOI:10.1186/1472-6920-14-162

${ }^{9}$ Layzer C, Rosapep L, Barr S. A peer education program: delivering highly reliable sexual health promotion messages in schools. J Adolesc Health. 2014;54(3 Suppl):S70-77. DOI:10.1016/j.jadohealth.2013.12.023

${ }^{10}$ Swartz S, Deutsch C, Moolman B, et al. Ensuring an optimal environment for peer education in South African schools: Goals, systems, standards and policy options for effective learning. Afr J AIDS Res. 2016;15(4):359-366.

DOI:10.2989/16085906.2016.1251474

${ }^{11}$ Nagy B, Varga A, Kovács VA, et al. The Hungarian Aqua Promoting Programme in the Young (HAPPY) - A best practice, sustainable community-based intervention program in Hungary; 5th Central European Congress On Obesity, Budapest, 2015.

12 Vass Z, Molnár L, Boronyai Z, et al. Zöld Könyv - A Testnevelés az Egészségfejlesztésben Stratégiai Intézkedések

(T.E.S.I 2020) szakpolitikai stratégia helyzetelemző kiadványa. Magyar Diáksport Szövetség, 2015.

${ }^{13}$ Rácz J. Iskolai egészségmagatartást fejlesztő programok. Iskolakultúra. 1995;5(13-14):91-94.

https://ojs.bibl.u-szeged.hu/index.php/iskolakultura/article/view/31065 (Elérve: 2019.11.02.)

${ }^{14}$ Németh Á. Diákvédelmi programok: A DADA és az ELLEN-SZER programok tapasztalatai. Új Köznevelés. 2014;70. évfolyam(1-2. szám):38-39.

${ }^{15}$ Lv XE, Chen HL, Zhang Q, et al. An Improved Bacterial-Foraging Optimization-Based Machine Learning Framework for Predicting the Severity of Somatization Disorder. Algorithms. 2018;11(2). DOI:10.3390/a11020017

${ }^{16}$ Falus A. Bemutatkozik az EDUVITAL: egy hazai ifjúsági egészségtudatossági és -nevelési program. Egészségfejlesztés. 2018;1. szám(LIX. évfolyam):83-85.

${ }^{17}$ Pénzes G, Bíró É. Egészségfejlesztő program középiskolások körében - Az alapállapot felmérés eredményei. Egészségfejlesztés. 2018;LIX. évfolyam(4. szám).

18 Somhegyi A. Teljeskörű iskolai egészségfejlesztés (TIE): Jelen helyzet. Különleges bánásmód.

2016;II. évfolyam (4. szám):61-80.

19 Timol F, Vawda MY, Bhana A, et al. Addressing adolescents' risk and protective factors related to risky behaviours: Findings from a school-based peer-education evaluation in the Western Cape. Sahara j. 2016;13(1):197-207. DOI:10.1080/17290376.2016.1241188

${ }^{20}$ Ochieng BMN. Adolescent health promotion: The value of being a peer leader in a health education/ promotion peer education programme. Health Education Journal. 2003;62(1):61-72. DOI:10.1177/001789690306200107

${ }^{21}$ Turner G, Shepherd J. A method in search of a theory: peer education and health promotion. Health Educ Res. Apr 1999;14(2):235-247. DOI:10.1093/her/14.2.235

22 Bandura A, \& National Inst of Mental Health. Social foundations of thought and action: A social cognitive theory. Prentice-Hall series in social learning theory. Englewood Cliffs, NJ, US: Prentice-Hall, Inc.; 1986.

${ }^{23}$ McLeod SA. Bandura - social learning theory. 2016. https://www.simplypsychology.org/bandura.html (Elérve: 2019.11.01.)

${ }^{24}$ Kirby DB, Laris BA, Rolleri LA. Sex and HIV education programs: their impact on sexual behaviors of young people throughout the world. J Adolesc Health. 2007;40(3):206-217. DOI:10.1016/j.jadohealth.2006.11.143

${ }^{25}$ Michie S, van Stralen MM, West R. The behaviour change wheel: a new method for characterising and designing behaviour change interventions. Implement Sci. 2011;6:42. DOI:10.1186/1748-5908-6-42 
${ }^{26}$ Járomi É, Vitrai J. Az iskolai egészségfejlesztés hazai és nemzetközi szemléletének bemutatása Egészségfejlesztés. 2017; LVIII. évfolyam(1. szám):36-48.

27 Vitrai J, Kimmel Z. Mennyire változtatható jogszabályokkal az egészségmagatartás? Mitől függ és hogyan változtatható az egészségmagatartás? I. rész. Egészségtudomány. 2015;LIX.(3):57-70.

${ }^{28}$ Corr M, Murtagh E. 'No one ever asked us': a feasibility study assessing the co-creation of a physical activity programme with adolescent girls. Glob Health Promot. 2019:1757975919853784. DOI:10.1177/1757975919853784

${ }^{29}$ Martin R, Murtagh E. Active Classrooms: A Cluster Randomized Controlled Trial Evaluating the Effects of a Movement Integration Intervention on the Physical Activity Levels of Primary School Children. J Phys Act Health. 2017;

14(4):290-300. DOI:10.1123/jpah.2016-0358

30 Taylor MJ, Arriscado D, Vlaev I, et al. Measuring perceived exercise capability and investigating its relationship with childhood obesity: a feasibility study. Int J Obes (Lond). Jan 2016;40(1):34-38. DOI:10.1038/ijo.2015.210

${ }^{31}$ Murtagh EM, Barnes AT, McMullen J, et al. Mothers and teenage daughters walking to health: using the behaviour change wheel to develop an intervention to improve adolescent girls' physical activity. Public Health. 2018;158:37-46. DOI:10.1016/j.puhe.2018.01.012

${ }^{32}$ Rohde A, Duensing A, Dawczynski C, et al. An App to Improve Eating Habits of Adolescents and Young Adults (Challenge to Go): Systematic Development of a Theory-Based and Target Group-Adapted Mobile App Intervention. JMIR Mhealth Uhealth. 2019;7(8):e11575. DOI:10.2196/11575

33 Balku E, Berki J, Csizmadia P, et al. EGÉSZSÉGJELENTÉS 2015. Budapest: Nemzeti Egészségfejlesztési Intézet; 2015.

${ }^{34}$ https://stats.oecd.org/ (Elérve: 2019.11.11.)

35 Szőnyi G. A pszichoterápia tankönyve. Medicina Könyvkiadó Zrt., Budapest, 2015.

${ }^{36}$ Prievara T. A 21. századi tanár. Egy pedagógiai szemléletváltás személyes története.

Neteducatio Kft. Modern Pedagógus Sorozat; 2015.

${ }^{37}$ Az Országos Mentőszolgálattal együttműködő Budapesti Orvostanhallgatók Egyesülete képviselőinek személyes közlése alapján; 2017-2019. 